\title{
Local democracy and public accountability in Uganda: The need for organisational learning
}

\author{
Commonwealth Journal of Local Governance \\ Issue 15: June 2014 \\ http://epress.lib.uts.edu.au/ojs/index.php/cjlg
}

\section{Stella Kyohairwe}

Uganda Management Institute

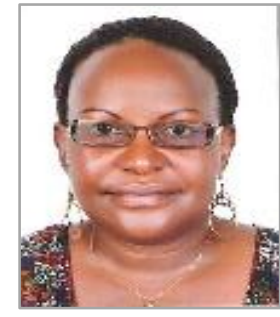

\begin{abstract}
:
The paper examines the impact of public accountability mechanisms in the Uganda's decentralisation local governments. Some of the common tools used for evaluation of local government performance have been presented and discussed including the baraza, village participatory democracy and the score-card reporting method. The orthodox theories of local governance and concept of democracy are bases for assessing the feasibility of public accountability in Uganda. The conclusions of the paper points to inefficiencies are the universal applicability of the concept of local democracy leading to a suggestion of new mechanisms of public accountability that emerge from organisational learning.
\end{abstract}

Key Words: responsiveness, accountability, representation, participation, popular authorization, democracy, organisational learning.

\section{Introduction}

Local democracy is an essential practice widely emphasised for increasing accountability of government systems. The answerability of public officers and the enforcement of the accountability mechanisms are paradoxically core intents and great challenges of local governance. The importance of local democracy advocacy therefore lies in the conviction that local democracy will enhance local government efficiency through a closer scrutiny of local service delivery. The assumption held is that the citizens have the competences for fully engaging in democratic governance through elected representatives or by participating directly in scrutinising local service delivery.

Governance whether at the central or local level must be seen to be democratic. Democratic governance implies a mandate for governments to create or strengthen mechanisms for public participation in decision-making, to abide by the rule of law, to increase transparency in public procedures, and to hold officials accountable (Kaufmann et al, 1999). The case for democratic governance aims at providing an institutional framework for participation by all 
citizens in economic and political processes, and promoting core universal human rights such as equality, fairness, justice, information access, and individual freedoms (Cheema, 2005).Because of its participative nature, democratic governance is considered as a great potential for increasing public accountability. Organisational learning is conceived as a mechanism for a change - adding to, transforming, or reducing - in organisational knowledge. Whilst this concept of organisational learning indicate a multitude interpretation from different scholars, this paper considers current approaches that focus emphasise routines as repositories of knowledge and they conceptualise learning as making and updating of routines in response to experiences

(Levitt and March, 1988). In this paper the Uganda's experience in local governance is explored. A linkage of the literature which local governance and local democracy to the practical tools of public accountability assessing the ideal mechanism of improving service delivery local governments

\section{Methodology}

The paper is based on a detailed documentation and legislation related to local governance and a number of reports on service delivery in local governments the public accountability mechanism used to assess the delivery. The common public accountability tools evaluated include the score cards, direct/participatory democracy at the village level and the public meetings commonly known as barazas ${ }^{l}$.

\section{Theorising and justifying local governance}

The theoretical background, explores some of the major paradigms that have greatly influenced local governance systems. The first set of theories stress the necessity of local governments basing on the orthodox propositions dated as far back as the $19^{\text {th }}$ century (Stoker, 1996). Among the proponents of these theories like John Stuart Mill (1861), Hill (1974), argue that local governments aid political participation, ensure efficiency and service delivery and oppose an overly centralised government. Their focus largely falls on increased autonomy, and creating a multi-purpose institution that provides a wide range of services.

Gerry Stoker identifies the second strand of theorists - the post-war reformers of the 1950s to the 1970s - such as Mackenzie (1961), Panter-Brick (1974), and Sharpe (1970) who stress local government's necessity to allow individuals to voice their needs, and to learn the art of practical politics. The reformers also focused on creating a moderate pressure group that promotes the un-organised interests for young people, women, and other marginalised social groups. It further aims to respond to the rising demand for public services by offering a more controlled and planned service delivery and a counterweight to the power of professionals the public services in their interests rather than society interests (King and Stoker, 1996:7-8).

\footnotetext{
${ }^{1}$ This term is explained in detail under the tools of accountability in the latter section of this paper
} 
Yet, Stoker's third strand of theorists includes commentators like Jones and Stewart (1985) who commend local government systems for their scope of local autonomy and decisionmaking and as essential units for ensuring that resources are better matched with the diversity of the local needs. This third strand seems to hold a more relevant to arguments in this paper, and suggests overtime, local governments became more desirable because of not only their potential to enhance participation but also to disperse political power to the communities to enable political choice and ensure proper resource utilisation. Local governments thus constitute a visible local bureaucracy, controlled by councilors who work closely with the technical officials and who are involved in the affairs of their locality. This increases opportunities for accountability and responsiveness.

\section{Democracy and public accountability}

The modern notion of democracy is rooted in the classical conception of ancient Greece philosophy of "rule by demos (many)" an idea influenced by the philosophy of Aristotle (as early as 300BC) who attempted to classify governments on the basis of who rules and who benefits from the rule. Aristotle's philosophical conclusion based on this view was that governments may be in the hands of single individuals (tyranny/monarchy), a small group (oligarchy/aristocracy) or in the hands of many (democracy/polity). While Aristotle acknowledged that in any of these governments category can be conducted to the interest of the rulers or to the benefit of the community, polity was comparatively considered to be better than a monarchy and aristocracy (Heywood 1994:69-70)

In its classical conception, the Athenian democracy was a direct/participatory democracy - a form of government by mass meetings and with each citizen qualified to hold a political office by lot or rota (Heywood, 2004:224). It was therefore characterised by citizen's popular control through direct deliberations and by equal participation of where all citizens were eligible for holding political office. Whilst direct democracy may be an admirable ancient Greece governance model, the modern government operating within a great society complexity permits less of direct democracy that was feasible with smaller communities. As such indirect/ representative democracy in which popular participation is through the act of voting is the most dominant. Representative democracy, Heywood observes, is not only infrequent and brief because of the term limit but also keeps the public at arm's length from the government by choosing representatives to govern on their behalf. 
The Athenian and indeed Aristotelian theory of democracy has widely influenced subsequent and scholarly readership conceptual interpretations. Among others, this paper borrows ideas of David Beetham that re-emphasise the classical thoughts on democracy through two categorical principles of popular control and political equality (Beetham in King and Stoker 1996:31-32) Beetham's emphasis is that popular control is characterised by popular authorisation of the key government decision makers through election by universal equal suffrage. Under such authorisation, the people constitute the rightful source of political authority (what he conceives as popular sovereignty). These mechanisms to Beetham should be aided by a written constitution that has been directly approved by popular vote whose change can only be through a referendum. The underlying assumption here is that since the rightful source of political authority lies in the people, they should then have a final say on the constitutional terms on which that authority is surrendered to others.

Popular authorisation is then seen as a mechanism for holding the representatives accountable for the policies and actions undertaken while in office and in the event of failure or abuse of trust by these representatives that should be turned out of office through the electoral process. Beyond the accountable representatives however, it is also assumed that popular control should enable a responsive government - of a pluralistic nature - that takes into account a full range of public opinion obtained by consultation for the formulation and implementation of law and policy.

Beetham's second principle of political equality and equal citizenship on the other hand constitutes such arguments as equal vote value for all, equal opportunities to stand for a public office for all social groups, and equal access to media. The general view under this democratic principle relates to fairness for all sections of the society and their opinions.

The above views on democracy are critical and informative in understanding how public accountability may be realised in the local in governments. Both direct and representative democracy if well practiced can enable not only a responsive government but also accountable leaders that are mindful of the wishes of those who authorise them and their power to withdraw their mandate in case of failure and mistrust of the representatives and the government in the service delivery. It remains important however to assess the possibilities of translation of such theory of popular control and political equality into realities of different international, national and local contexts given that the political, economic, social and technical empowerment of citizens may be paramount determinants in the use of these principles. 


\section{Conceptualisation of public accountability}

Overall conceptualisation of public accountability framework includes three facets: political, administrative and social accountability as illustrated in Figure 1 below:

Figure 1: A framework for Local governance and public Accountability

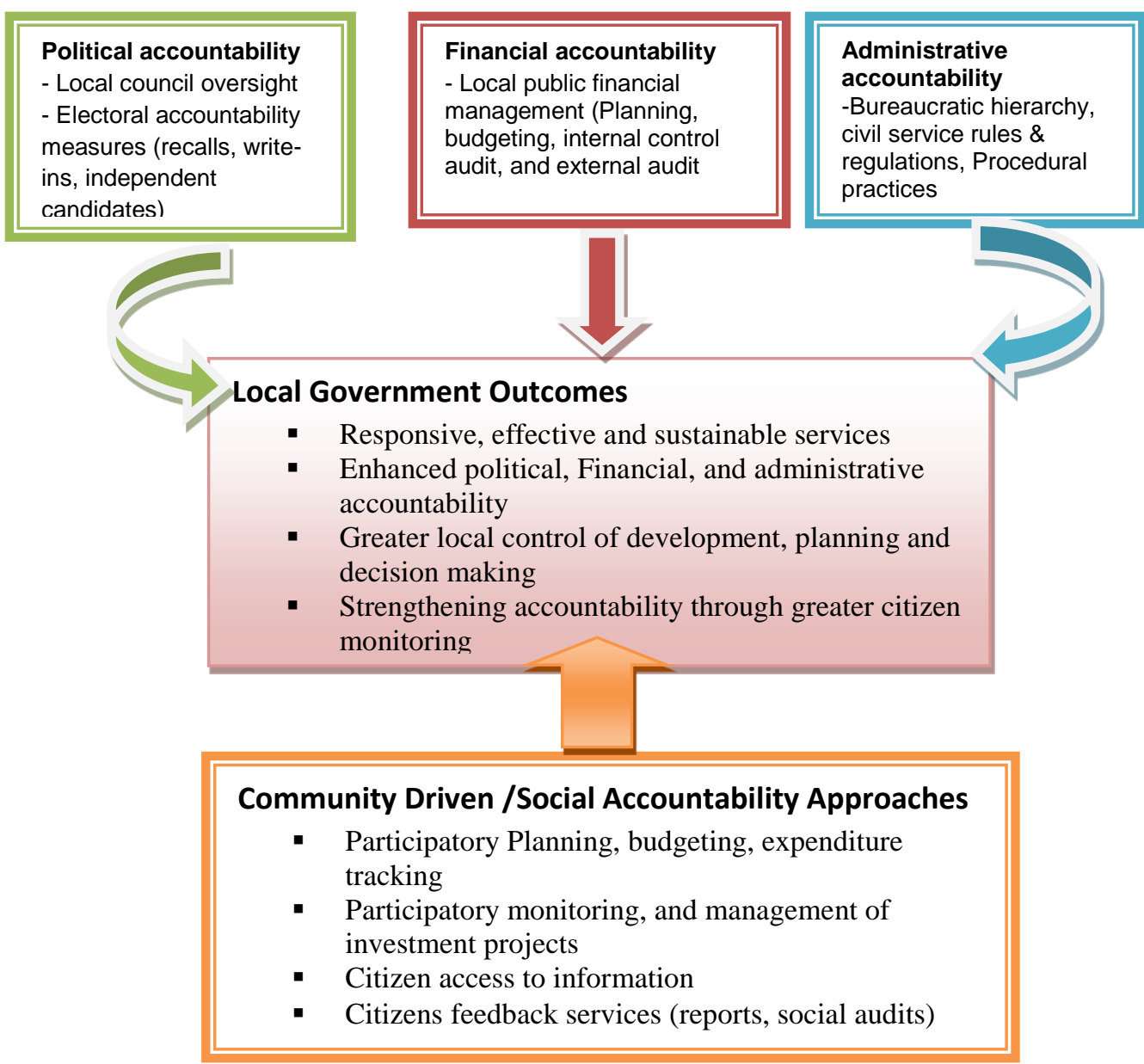

Source. Adopted and modified from Yilmaz, et al (2008): Local Government Discretion and Accountability: A Diagnostic Framework for Local Governance

The framework in Figure 1 above is a modification the conceptual framework for analyzing the factors that improve local governance put forward by Yilmaz et al (2008). Political, administrative, and fiscal accountability are essential elements contributing to realisation of local government outcomes of sustainable service delivery, such as increased local control of development planning and decision making, and strengthened accountability through citizens monitoring. Relating to the core argument of this paper, community driven/social accountability approaches are indicated as most critical in ensuring the desirable attainment the local government outcomes. 


\section{Local democracy in Uganda and its influence on accountability}

Whist local governance in Uganda dates back to the pre-colonial and the colonial era, the current agenda of decentralisation and local democracy started in the mid-1980s when the National Resistance Army (NRA) came to power and set up Resistance councils (now called local councils)(MOLG, 2006). During the following years, local governments and local council units were modified by the extended legal framework of the Local Government Statute of 1993, the Uganda Constitution and the Local Government Act, 1997 (CAP 243). Effecting local democracy was meant to be achieved through political decentralisation.

Uganda's intensified policy of decentralisation was seen as a cornerstone for improving service delivery and strengthening good governance especially at the beginning of the 1990s. Over the years, government has sought to address the deficiencies in public service delivery at the local level by strengthening central government monitoring programs. Such monitoring is often done through monitoring units and inspectorates in central government ministries, public accounts committees of Parliament, constitutional and statutory accountability bodies, local accountability committees and more recently administrative initiatives such as barazas, task forces and other forces of inquiries. Government driven performance monitoring initiatives are complemented by a wide range of initiatives by civil society organisations ${ }^{2}$

\section{Ugandan local governance: - a political and administrative web}

The Ugandan local governance system consists of a complex structure, with a broad geographical rural-urban classification, and different hierarchies of local government organisations in rural and urban areas (Table 1):

Table 1: Local Government Structures in Uganda

\begin{tabular}{|c|c|c|c|c|c|}
\hline & \multicolumn{5}{|c|}{ LOCAL GOVERNMENTS AND ADMINISTRATIVE UNITS CLASSIFICATION BY LEVEL } \\
\hline \multirow{5}{*}{$\begin{array}{l}\text { GEOGRAPHICAL } \\
\text { CLASSIFICATION }\end{array}$} & & Local Gov't & $\begin{array}{l}\text { Higher Local } \\
\text { Government }\end{array}$ & $\begin{array}{l}\text { Lower Local } \\
\text { Government }\end{array}$ & $\begin{array}{c}\text { Administrative } \\
\text { Units }\end{array}$ \\
\hline & Rural & District & $\begin{array}{ll}\text { District } & \text { Council } \\
\text { (LC5) } & \end{array}$ & Sub-County (LC3) & $\begin{array}{l}\text { LC1(Village) } \\
\text { LC2 (Parish) } \\
\text { LC4 (County) }\end{array}$ \\
\hline & $\begin{array}{l}\text { Rural- } \\
\text { Urban }\end{array}$ & & & $\begin{array}{l}\text { Town Councils } \\
\text { (LC3) }\end{array}$ & $\begin{array}{l}\text { LC1 (Village) } \\
\text { LC2 (Ward) }\end{array}$ \\
\hline & Urban & City & City Council (LC5) & $\begin{array}{l}\text { City Division } \\
\text { Council (LC3) }\end{array}$ & $\begin{array}{l}\text { LC1 (Village) } \\
\text { LC2 (Parish) }\end{array}$ \\
\hline & & Municipal & & $\begin{array}{l}\text { Municipal Division } \\
\text { (LC3) }\end{array}$ & $\begin{array}{l}\text { LC1 (Village) } \\
\text { LC2 (Parish) }\end{array}$ \\
\hline
\end{tabular}

Source: Local Governments Act, CAP 243: Sec. 3\& 45

\footnotetext{
${ }^{2}$ One example of such organisations is the Uganda Debt Network (UDN), that has been undertaking a series of community level monitoring and evaluation of government programs through using a range of tools including Community-based Monitoring and Evaluation Systems (CBMES)
} 
As highlighted in Table 1, Uganda's comprehensive local government system is made of a five-tier pyramidal structure of local councils (LCs). These local councils are classified as rural councils and urban councils. They are also classified as local government and administrative units (Uganda, $1997 \mathrm{Sec} 3$ ).

Within the in rural areas a five tier system consists of:

- $\quad$ the Village (LC1),

- $\quad$ Parish (LC2),

- $\quad$ Sub-County (LC3),

- $\quad$ County (LC4), and

- $\quad$ District (LC5).

In urban areas this consists of:

- $\quad$ the Village (LC1),

- Ward or Parish (LC2),

- Municipal Division, and City Division (LC3),

- $\quad$ Municipality (LC4), and

- $\quad$ City (LC5).

Urban-Rural structures consists of town councils (equivalent to sub counties) in a purely rural setting and Town boards which are classified rural-emerging trading centres

The legislation classifies a village, a parish/ward and a county as administrative units which exist for purposes of aiding administration of local governments through provision of advice on matters pertaining the respective administrative unit level and monitoring delivery of services in the area of jurisdiction among other roles.

\section{Local government and representative democracy}

The present local government councils comprise a chairperson (or a mayor in a city) and one councillor for each electoral ward. Local government representation thus is through single member constituencies. An electoral area of a district council is a sub-county whilst in the municipal council councillors represent parishes/wards. In addition however, the local councils consist of other councillors that include: 2 youth councillors (1 male and 1female); 2 councillors with disabilities, ( 1 male and 1 female); and women councillors that form onethird these councils ${ }^{3}$ (LGA 1997: Sec $10 \&$ 23).Local governments also include executive committees with a chairperson, vice chairperson and up to three secretaries of whom at least one must be a female (Sec 16 and 25 of the Act). The Local Governments Act also mandates these councils to select a speaker, a deputy speaker and at most three Standing Committee chairpersons from amongst the councillors irrespective of gender. The impact on the entire local government electoral process by the multi-party dispensation that came into effect in 2006 seems to be insignificant taking into account that the National Resistance Movement (NRM) ruling party is the majority party that dominated the grassroots democracy. Party politics can therefore be said to be insignificant especially in rural areas.

${ }^{3}$ The other mentioned categories form two thirds of the council 
The higher tier of local government administrations, through their leadership chairperson/mayor, vice chairperson, and a number of secretaries ${ }^{4}-$ are charged with responsibility of initiating and formulating policy, overseeing the implementation of the government and council policies, monitoring and coordinating the activities of the council and the NGOs operating within the local government, and recommending persons to be appointed on council commissions and boards. The leadership is also responsible for solving disputes referred by lower local government councils and the evaluation of council plans and programs (LGA 1997: Sec 18 \& 26). Lower tiers of local government, including municipalities, are also charged with maintaining law, order and security; initiating and supporting self-help projects; and linking the government and local people (Kyohairwe 2009).

The composition of administrative units however differs modestly from that of local governments. Whilst the Local government councils consist of representatives selected directly from electoral areas by adult suffrage the administrative unit councils, with the exception of village council, are constituted of executive members of immediate lower councils. Village councils include all persons of 18-years of age or above in that village from whom the village selects a 10 -member executive committee. Parish administrative units (or wards in towns) are made up of all members of the village executive committees within that parish, while at a county administrative unit comprises all members of the sub-county executive committees within that county. Like the village level, at the parish administrative council, consists of a ten-member committee selected amongst the council members.

Although the county administrative unit council consists of the sub-county executive committees, it is only mandated to select a chairperson and vice chairperson but, unlike other of administrative units, has no other committees (LGA 1997). The functions of the administrative units include monitoring of services, assisting in maintaining law and order and highlighting to the political or administrative staff any matter that raises their concern. The County AU is further responsible for advising the area Members of Parliament on all matters pertaining to the county and is also charged with resolving problems or disputes referred to them by relevant sub-counties. Aparish AU is also responsible for resolving disputes within village councils.

\footnotetext{
${ }^{4}$ Local government political secretaries are a.k.a Ministers in charge of respective sectors
} 


\section{Tools for public accountability under Uganda's local democracy}

\section{- $\quad$ Participatory democracy through Local councils}

For over two decades, participatory democracy has been used as a tool of local democracy in Uganda especially at the in village (LC1). Membership of the village includes all persons of 18 year of age or above residing in the area. Through its executive committee of ten elected members (LGA 1997, Sec 47(2) the village is responsible for duties such as maintaining law and order, initiation and participation in self-help projects, and serves as a communication channel between higher local councils and the people in the area. It is also charged with monitoring administration and the projects in its area. These functions imply that the villages have significant responsibility in ensuring accountability in the service delivery within the localities. The decision making at the lowest local council is normally affected through regular meetings on the matters that affect respective communities at this level. Many times, because of the relatively small size of the villages, decisions are taken through participatory manner, where all members attend meetings and contribute to political debates as shown in figure 2 below.

Participatory democracy as illustrated above is one popular form of enhancing accountability and responsiveness since the people in need of service delivery are directly involved in the making critical decisions related to such services. Through direct democracy, all members of the village (through adult suffrage) vote for their executive representatives. Once elected, the village members hold regular meetings with their representatives on matters affecting their respective villages. The constitution and Local Government Act (CAP 243 Section 47) give the village members a mandate to remove a chairperson or a member of a village executive committee if such executive member is incompetent, corrupt, abuses office or has other misconduct that is affect the performance of such a member as per the wishes of the people.

We realise that this is consistent with the principle of popular control theorised in David Beetham's scholarly work. Ideally the village participatory democracy further offers an opportunity to all people at the village level opportunities of political equality in decision making and a relatively equal voice for holding their leaders accountable. These assumptions of popular control and political equality not withstanding though, it may quickly be noted that it is more theoretically conceived than practically feasible for village members to effectively hold their leaders accountable. This may be in the event that local people may be incapacitated - have limited knowledge in governance matters, less interest in political issues, less power in voicing their concerns - to the extent they are often easily manipulated, coerced or ignored by their leaders who instead keep serving their own wishes than those of the represented with immunity facilitated by the democratic failures in larger governance system structures. 
- The Baraza Tool for Public Engagement in Local Democracy and Accountability

First adopted in 2009, the barazas ${ }^{5}$ are a Presidential initiative to create space for citizens discussion and evaluation of the performance of government programs within their respective communities. The term baraza in Uganda is applicable to are sub-county fora/dialogues where local people hold Government officials, especially at Local Government level, to account for the resources spent on public programmes in their areas - normally held bi-annually.

At its inception, the baraza process was piloted in 10 districts and by August 2012, it had been rolled out to about 68 districts with plans to cover the whole country in the next three years. The baraza is conducted twice a year at the sub-county level and is spearheaded by the Office of the Resident District Commissioners (RDCs) - presidential representative - at the district level in their respective districts. At the national level, the barazas initiative is run by the Office of the Prime Minister (OPM) and monitored by its department of Monitoring and Evaluation of the OPM office (OPM 2011). Barazas according to the OPM are designed to empower communities and citizens to demand better service delivery and accountability,; and improving information and communication about government programs and projects. The program was further intended to identify policy and implementation challenges that affect the government's performance management system. The process is intended to provide meaningful recommendations to government on measures to improve service delivery and reactivate the supervision and monitoring functions of RDCs.

The barazas bring together stakeholders from central and local governments, service providers or bureaucrats, and the public/community - the users of services, and provide an opportunity for sharing public information with local communities. It is focused on effective monitoring of public service provision and gives an arena for the community to demand for accountability from bureaucrats. The baraza meetings are characterised by four identifiable aspects that involve assessment of the following

- the planned services for the community;

- what was actually delivered;

- what was actually spent on different locations; and

- the issues and challenges have emerged with proposals of the way forward.

The entire process is therefore aimed at improving civic participation and public accountability with a focus on critical sectors including Agriculture (especially regarding the National Agriculture Advisory Services program) education, water and sanitation, health and roads (OPM 2011)

\footnotetext{
${ }^{5}$ Baraza(s)is Kiswahili language word meaning a public meeting, which is used as a platform for creating awareness, responding to issues affecting a given community, sharing vital information, providing citizens with the opportunity to identify and propose solutions to concerns.
} 
The barazas accountability performance has been felt in some areas. Some reports from the office of Prime minister indicate achievements that have been realised in some of the districts. Two of the districts in the report include Lira and Amaru Districts in Northern Uganda. In Lira District, the community barazas reports available largely focus on challenges of effective access to justice highlighting the public dissatisfaction with inadequacies in handling of court cases and related records by the police and the judiciary (http://justicecentres.go.ug/). A detailed account of service delivery baraza report however is from Amuru district. In two of the subcounties of Amuru district where the barazas were held, the residents took the opportunity to critique and demand explanation for government programs and funds they felt were inappropriately spent including road construction, the Northern Uganda Social Action Fund (NUSAF), National Agricultural Advisory Services (NAADS) and Peace Recovery and Development Plan (PRDP). Assessing the National Agricultural Advisory Services, the public is noted to have raised extreme concerns that the project implementers were distributing pigs "as small as edible rats" and yet they exaggerate the prices to the tune of 300,000 Uganda shillings. In education, the local people also demanded to know why some schools were charging extra fees on top of the funds disbursed for Universal Primary Education, while in the roads sector, the state of the roads in the district was critically considered not be reflective the existing government personnel and financial releases in this sector. Overall however several members of the community expressed excitement at the initiative of empowering them to demand accountability from the government workers (IRN News of 24th August 2011, OPM 2012).

The baraza reports in both Districts indicate that the local community is active in pursuing accountability of public servants though mechanisms of participation in the evaluation of community programs. The critique of community engagement through barazas however is that most local people involved in the barazas, including district leaders have limited factual information on matters being raised which limits their efficiency in their discussions with their political and bureaucratic leaders appropriately. Other hiccups highlighted in the use of baraza tool is also considered as the timing - in the morning hours - that usually proves problematic for public attendance because many people are at work. The venue of barazas being at SubCounty headquarters is also distant and inconvenient for some community members that would like to attend. These hindrances of course, imply a subsequent effect on the input of the public and are clear indicators of limited popular control and political equality of all the community members as it ought to be under a proper local democracy, at least according to David Beetham's view. 


\section{a) Score-cards reports and local democracy}

The score-card was a tool developed by the Advocates Coalition for Development and Environment (ACODE) to deepen decentralisation and the delivery of effective governance and quality goods and services. The reports provide an assessment of local government councils, chairpersons, speakers and councilors to determine how well they perform their political responsibilities and functions, although this paper focuses on overall local government council performance. The council performance assessment criteria include legislative representation, accountability to citizens, planning and budgeting, and monitoring of service delivery in different sectors. The delivery of the services in the different sectors within the districts is another performance criteria. This paper presents two case studies of Mpigi and Luwero districts in central Uganda in which the score-card tool was used to enable a further analytical stance of the tool relevance in service delivery.

Luwero and Mpigi are two of the 20 district local councils that were assessed using the Local Government Councils' Score-card in 2009/10. The summaries in Cases 1 and 2 are reports derived from score-cards completed by local community participants. The findings are summarised below. 


\section{Case 1: Score-card reports for Luwero District}

Legislative Representation:Scored 17 out of 25. The district council conducted business in accordance with the rules of procedure. The council passed a number of motions on service delivery, accountability and other relevant areas; received and handled petitions and letters submitted to it by the electorate. However it performed poorly in holding public hearings.

Accountability to citizens: scored 21 out of 25 points. The council maintained the practice of displaying public funds and ongoing projects on public notice boards. The display of funds was common at both the district as well as sub-county The display of funds was common at both the district as well as sub-county headquarters. The systems to ensure administrative accountability - issues of Audit and Public Accounts Committee (PAC) reports were in place.

Planning and budgeting: scored 16 out of 25 points. The district local government relied heavily on central government conditional grants to finance its budget. Yet, to be effective, the council must have the independence and autonomy to budget and allocate resources. The Council had approved all the basic budget and planning instruments including the district budget framework paper, the three-year district development plan, the district capacity building plan, the district revenue enhancement plan, and the district work plan. Although there were reported initiatives by council to raise local revenue and engage central government on revenue enhancement there was no substantial increase in local revenue or discretionary funding which would increase the planning and budgeting autonomy of the council.

Monitoring Public service delivery: scored 21 out of 25 points. The district council had quarterly report for every visit to monitor the delivery of National Priority Program Areas (indicated in the council minutes). It managed to fulfill the Constitutional role of overseer or local government employee performance in provision of services and monitor the provision of government services or the implementation of projects in their areas as provided for under Article 176(2) (g) of the Constitution.

Overall assessment in service delivery in different Sectors: In Education sector, the intake increased from $86.8 \%$ in 2007 to 118.3 in 2009. The number of pupils Primary leaving Exams (PLE) passing in Division 1 declined from 16.4 in 2003 to $7.4 \%$ in 2009. There were challenges of the poor classroom infrastructure in many of the schools in the district characterised by dilapidated and at times incomplete structures.

In health, access to medical services remained a challenge due to few health units and medical workers. Improvement in some areas like availability of HIV services (37\% in 2006 to $93 \%$ in 2009) were registered but there were some declines in other areas such as immunisation and health service utilisation. Bad conduct of the health workers, manifested in the high levels of absenteeism and negligence towards patients.

The access of water services in the district was at $75 \%$ while functionality of the water sources was at $80 \%$ for the rural areas. The provisions of to clean water had not improved though, for the majority of local residents. 


\section{Case 2: Findings of Mpigi District}

Legislative Representation: scored 11 out of 25. For three years, the district council conducted business without following any rules of procedure, did not enact any ordinances during the year under review, and never held the meetings on time. It performed poorly in holding public hearings.

Accountability to citizens: scored 19 out of 25. It had an established practice of displaying public funds and ongoing projects on public notice boards. The display of funds was common at both the district as well as sub-county headquarters. In terms of political accountability, the district council chambers had a provision for a citizens' gallery and the council allows citizens to observe council sessions and make contributions. Council accorded ample time for the discussion of all sectoral committee reports.

Planning and Budgeting: scored 13 out of 25. It relied heavily on central government conditional grants to finance its budget. Yet, to be effective, but can do well with the independence and autonomy of the budget and allocation of resources. The council had approved all the basic budget and planning instruments: the district budget framework paper, the three-year district development plan; the district capacity building plan; the district revenue enhancement plan and the district work plan. Although there were reported initiatives by council to raise local revenue and engage central government on revenue enhancement, there was no substantial increase in local revenue or discretionary funding which would increase the planning and budgeting autonomy for the council

Monitoring public service delivery: District Council obtained Maximum score in overseeing the performance of persons employed by the government in service delivery. The Council sectoral committees undertook regular monitoring, and produced regular reports. The council's deliberations had substantial discussions on a number of service delivery issues, with commitment to follow up emerging issues

\section{Overall assessment in service delivery in different Sectors:}

In education sector, Enrolment percentages had risen from 42.7 per cent in 2007 to 69.7 per cent in 2009; and there were constant pupil-teacher ratio over the previous 5 years . The primary leaving examination had a major slump in performance over the years with a drop in Division One - from 6.9 in 2003 to less than $2 \%$ in 2008

Health facilities were few, with an average distance to a health facility in the district is 7 $\mathrm{km}$ while the doctor-to-population ratio stands at about 1:41,023. Infant mortality ratio is 97 per 10,000 live births.

Major sources of water in the district were piped distribution networks in the urban areas and protected springs in the rural areas. $79 \%$ of the urban and $81 \%$ of the rural population access clean water sources. The functionality of these water sources, especially shallow wells in the rural areas presents a particular challenge, with 252 sources (33\%) being nonfunctional

Source: Muyomba-Tamale, L., et al. (2011). Local Government Councils' Performance and Public Service Delivery in Uganda: Mpigi and Luwero District Council Score-Card Reports 2009/10. 


\section{Construing the council score-cards reports}

Legislative representation was found to be relatively poor in Mpigi and moderate in Luwero. This implied that the representatives were not effectively representing their electorates since in some instances they never followed rules and regulations and never involved people in public hearings that are critical mechanisms of enforcing public accountability. The overall observation was that there was limited popular control and as a result public accountability might have been compromised.

On contrary however, direct indicators of financial accountability to citizens seemed to have scored slightly higher as was illustrated by open publicity of the funds obtained by the districts and sub-counties. The study report also highlighted the transparency of councils that provided a citizens' gallery during council deliberations. Administrative accountability could be deduced from audit and public accounts committee reports.

The responses on planning and budgeting in both districts however suggested little influence from councilor's or citizens in ensuring local accountability. While it is true that councils do engage in the planning and budgeting process and oversight functions, the pathetic realities that impinge their accountability stem from limited financial autonomy from the central government, and lack of control over use of funds. The center dictates budgetary priorities which contradicts the assumptions for democratic decentralisation and local governance that assumes local prioritisation of needs.

On the monitoring of public services, the scores were admirable indicating that both district councils were highly involved in the regular monitoring the government programs. The follow-up by councilors, on the activity by local government bureaucrats demonstrate possibilities of enhanced financial accountability in the service delivery. Such monitoring is meant to establish the performance progress and quality to demonstrate administrative accountability.

A final analysis of the performance score-cards indicates persistent problems across the sectors of education, health and water which are meant to address critical social needs. A decline in pupil enrolment rates and academic performance in PLE, persistent health facilities and resources plus limited water access by the rural poor are clear indications of the controversies in the orthodox assumptions relating to the local democracy and decentralisation. 
The findings in this sector suggest that not every local democracy leads to responsive and accountable actions of the political leaders; and that perhaps a scrutiny of other systemic factors for improved service delivery may override local democracy thinking for improved service delivery. Indeed dilemmas of decentralisation, local democracy, and service in Uganda for over two decades in Uganda can be detected in such illustrations as below:
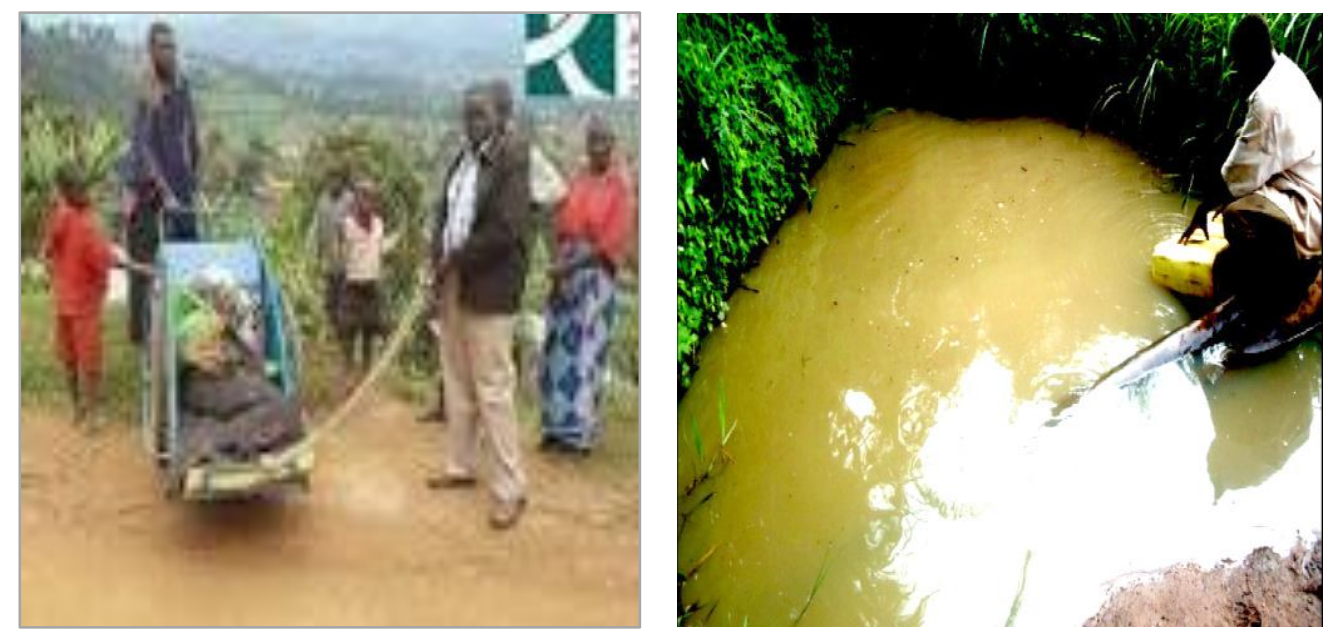

Left: A community "ambulance" (a locally made stretcher) commonly used in some remote places in Uganda to transport patients and pregnant mothers to health facilities.(source: http://wrauganda.blogspot.com/2013/11/unreliable-referral-system-make-poor.html).

Right: A resident drawing contaminated water in one of the villages in Luwero

Source: ACODE Digital Library, in Muyomba-Tamale, 2011

The score-card tool and the related reports presented above indicate that if well used the tool can solicit and raise issues of performance in the local government. This assessment if done by the local people is likely to offer an opportunity to them for obtaining information and raising matters of concern to which local government leaders can direct attention. This suggests that there is a likelihood of public accountability realisation as a result. We should appreciate however that the tool may require a relatively higher level of knowledge, information and analytical thinking which may disadvantage the local people with low education and less capacities to assess the given parameters of district performance. 


\section{Conclusion and recommendations}

Public accountability is closely linked to local democracy both in theory and practice. Local governance largely influenced by orthodox assumptions of efficiency and effectiveness in service delivery and as a way of increasing participation has been extensively adopted in Uganda since 1980s. Influenced by Athenian and Aristotelian theory of democracy and the views of the subsequent scholars in democratic governance (such as David Beetham) decentralisation and local governance has been adapted aiming at increasing public accountability.

Uganda's search for public accountability has been associated with community driven social accountability approaches that among many other tools has implemented participatory democracy especially at the village level, baraza public meetings for public expenditure and service delivery assessment, and scorecard reports for performance evaluation. The involvement of citizens at the grassroots in these government performance assessments undoubtedly is a direct way of ensuring public accountability. Controversies of effective public accountabilities remain persistent for such challenges associated with the limited empowerment of the majority of the citizens involved in the participation process for government performance evaluation. Observations relating to limited information and knowledge on the subject being assessed, as well as economic vulnerability due to poverty that subjects them to being manipulated which affects objectivity, poor timing of participatory assessment schedules and inaccessible venues for participation are great hindrances to equal involvement of all citizens. Consequently popular control and political equality principles of democracy as suggested in Beetham remain elusive in the Ugandan context. The suggestion for improving public accountability from this paper is that instead of increasingly initiating additional mechanisms of involving the masses in public accountability, it is important to assess and learn from our own routines and experiences - as suggested in social organisational learning. This will enable us to assess the extent of citizen's ability to control the actions of their representatives and to influence the responsiveness of the government. In the event that personalised efforts of citizens may not influence public accountability, mechanisms for enhancing concerted efforts of civil societies may be a comparative option. 


\section{References}

Beetham, D (1996) Theorizing Local Democracy and Local Government. In King, D. and G. Stoker, Eds. (1996). Rethinking Local Democracy. London, Macmillan Press Ltd

Beetham, D (1999). Democracy and Human Rights. Cambridge, Polity Press.

Bennet C,.J, and Howlet M,. (1992): Lessons of learning: Reconciling theories of policy learning and policy. Policy Sciences, Vol 25 (3) p275

Cheema. G. S., (2005), Building Democratic Institutions. Governance Reforms in Developing Countries. Bloomfield, USA, Kumarain Press Inc.

Heywood, A. (2004). Political Theory: An Introduction. New York, Palgrave, Macmillan.

Kaufmann. D., Kraay, A., and Zoido-Lobaton, P., Governance Matters, Policy Research Paper 2196, World Bank, 1999.

Kyohairwe.S. (2009) Gendering Political Institutions: Opportunities, Significance and Challenges of women in local politics. VDM Verlag Muller Aktiengsellschaft\&Co.KG, German

Levitt, Barbara; March, James G. (1988) ; Organisational Learning in: Annual Review of Sociology 14 (1988): 319-340

MOLG.(2006). Decentralisation Policy Strategic Framework. . Kampala: Government of Uganda.

The local governments Act 1997 (CAP 243)

The Uganda constitution 1995 (accessed 07/09/2011)

www.parliament.go.ug/new/images/stories/constitution/Constitution_of_Uganda_1995.pdf

UN-HABITAT Report (2002): Local democracy and decentralisation in East and SouthernAfrica: Experiences from Uganda, Kenya, Botswana, Tanzania and Ethiopia

Yilmaz.S., Beris.Y., and Serrano-Berthet.R.,(2008): Local Government Discretion and Accountability: A Diagnostic Framework for Local Governance. Social Development Papers: Local Governance \& Accountability Series; Paper No. 113 July 2008

OPM (2011). Countrywide Implementation of the Baraza Initiative:Quarter 2 Draft BARAZA Consolidated Report. Kampala: Government of Uganda.

Office of the Prime Minister. (2011). Draft Report on Countrywide Implementation of the Baraza Initiative. Kampala: Government of Uganda.

OPM (2012). Government Annual Performance Report 2010/2011. Kampala: Government of Uganda. http://opm.go.ug/resource-center/departmental-publications/department-of-policy-coordinationmonitoring-evaluation1.html 